\title{
Diverse Clinical manifestations in Sickle Cell Anemia: study in District Amravati, MS India.
}

\author{
Varsha Wankhade ${ }^{1 *}$, Andhale RB ${ }^{1}$ and Sangita Lodha ${ }^{2}$ \\ ${ }^{1}$ Department of Zoology, University of Pune, Pune, Maharashtra, India \\ ${ }^{2}$ Thalassemia center, Jankalyan Blood Bank, Nashik, Maharashtra, India
}

\begin{abstract}
Background of Study: Sickle cell anemic patients show diverse clinical symptoms with varied complications influenced by genetic, environmental and socioeconomic factors. Sickle cell anemia is prevalent in district Amravati, MS, India.

In the present study, some symptomatic presentation of sickle cell anemic patients district Amravati, MS were studied in order to know pathophysiological complications going on in sickle cell anemia. In total, 67 sickle cell anemic patients were investigated. Information regarding some clinical symptoms was gathered from the patients and filled in the data sheets. It was observed that $77.77 \%$ patients frequently suffer from fever, $85.18 \%$ patients suffers from joint and chest pain, $81.48 \%$ experience recurrent tiredness, $85.18 \%$ experience shortness of breath, swelling of abdomen was found in $29.62 \%$ patients, $48.14 \%$ experience unusual headache. From the study of data sheet it was found that $29.62 \%$ sickle cell patients suffer from jaundice. In $51.85 \%$ patients, growth was delayed. Recurrent occurrence of pain episodes was observed in $55.55 \%$ patients. Thus sickle cell anemia in district Amravati shows variable clinical manifestations in variable percentage. Thus it is proposed to manage the disease properly as soon as it is detected.
\end{abstract}

Keywords: Sickle cell anemia; Clinical features; Amravati; Symptoms

\section{Introduction}

Sickle cell anemia is a genetic disorder, caused by mutation in the hemoglobin coding gene. Sickle cell anemia is caused due to substitution of valine for glutamic acid at sixth position of beta globin of hemoglobin $[1,2]$. This mutated and defective hemoglobin is less soluble and after deoxygenation undergo polymerization causing distortation of shape of (RBCs) Red Blood Cells [3]. The pattern of inheritance of this disorder is recessive. Sickle cell anemia is distributed widely in Africa, Asia and Middle East, the parts of the world where malaria is endemic. Sickle cell anemia carrier (trait) are asymptomatic and generally are not aware of the diseased gene they carry [4].

Sickle cell anemia, or homozygous sickle cell disease, affects about 250,000 children worldwide every year; most of them die before they attain age of two years due to multiple strokes $[5,6]$. Life expectancy of sickle cell patients is less. Sickle cell anemic patients die due to complications like pain, acute chest syndrome and stroke, pulmonary hypertension, renal failure, infections and unknown etiology [7].

Sickled RBCs cause severe vaso-occlusive phenomena. The severity of the complications of this disease varies from patient to patient such as severe obstruction of blood vessels which prevents supply of oxygen to downstream tissues, hemolytic anemia [8]. In sickle cell anemia children and adults experience painful vaso-occlusive events which are generally dealt with aggressive hydration, anti-inflammatory and narcotic analgesics. Patients are treated with drugs like hydroxyurea to manage the complications. This drug is able to modify pathogenesis of the disorder. In the developed countries, the mortality rate of sickle cell anemic children is 0.5 to 1.0 per 100,000 but this rate is high in developing countries which are recorded to be 15.5 per 1000 children [9]. Sickle cell anemic (SCA) patients need to have regular blood transfusions and may have high risk for infections of hepatitis and others. Recurrent blood transfusions lead to cause high level of iron in serum. There could be damage to the organ such as endocrine organs, hepatic parenchyma cardiac myocytes by ROS-mediated lipid peroxidation due to accumulation of iron $[10,11]$.
Sickle cell anemic patients present heterogeneous clinical symptoms with acute and chronic complications which could be modified by genetic, environmental and socioeconomic factors $[1,2]$. Sickle cell anemia affects many organ systems [12-14]. In the present study symptomatic features in sickle cell anemic patients are tried to be explored out in order to observe pathophysiology and complications in such patients.

\section{Materials and Methods}

\section{Study area and population}

The study population consisted of 67 randomized subjects with Sickle cell anemia from district Amravati, Maharashtra, India. The mean age of the selected patients was 20.48. This study was approved by Institutional Human Ethics Committee. Written consent from each participant was taken.

\section{Study of some clinical parameters}

Patient's health history was taken to understand the various complications going on in the body of the patients. Data sheet was filled on the basis of questionnaire answered by patients. Socioeconomic status of the patients was noted. Pedigree was developed on the basis of family history given by the participants. For few parameters such as pulse rate, delayed growth, fever etc patients were examined.

*Corresponding author: Varsha Wankhede, Department of Zoology, University of Pune, Pune, Maharashtra, India, E-mail: varsha3w@unipune.ac.in.

Received January 24, 2013; Accepted March 27, 2013; Published March 31, 2013

Citation: Wankhade V, Andhale RB, Lodha S (2013) Diverse Clinical manifestations in Sickle Cell Anemia: study in District Amravati, MS India. J Blood Disorders Transf 4:136. doi:10.4172/2155-9864.1000136

Copyright: (c) 2013 Wankhade V, et al. This is an open-access article distributed under the terms of the Creative Commons Attribution License, which permits unrestricted use, distribution, and reproduction in any medium, provided the original author and source are credited. 
Citation: Wankhade V, Andhale RB, Lodha S (2013) Diverse Clinical manifestations in Sickle Cell Anemia: study in District Amravati, MS India. J Blood Disorders Transf 4:136. doi:10.4172/2155-9864.1000136

Page 2 of 3

\section{Result and Discussion}

\section{Study of clinical parameters}

Clinical parameters like recurrent fever, joint and chest pain, recurrent tiredness, shortness of breath, swelling of abdomen, unusual headache, jaundice, delayed growth, recurrent occurrence of pain episodes, yellow eyes etc., were observed in sickle cell anemia. It was observed that $77.77 \%$ patients suffer from fever, $85.18 \%$ patients suffers from joint and chest pain, $81.48 \%$ experience recurrent tiredness, $85.18 \%$ experience shortness of breath, swelling of abdomen was found in $29.62 \%$ patients, $48.14 \%$ patients experienced unusual headache. In $51.85 \%$ patients, growth was delayed. Recurrent occurrence of pain episodes was observed in 55.55 patients. Some clinical parameters of sickle cell anemic patients are shown in figure 1. These complications may be due to hypoxic condition of SCA.

Clinical manifestation in Sickle cell disease varied and it is not well understood and explained by single mutation. Variability regarding symptoms is observed in the frequency and intensity of painful vaso-occlusive crises and also in the degree of organ dysfunction. Pathophysiology appears because of combined effects of hemolysis and vaso-occlusion. Hemoglobin picks up and releases oxygen repeatedly and undergoes polymerization and depolymerization leading to hemolysis. As a result free hemoglobin uses significant amount of nitric oxide (NO) [15] that results in abnormal regulation in the vascular homeostasis [15-17].

In SCA, important cause of morbidity and mortality is ACS (Acute Chest Syndrome) which found to occur in $45 \%$ of patients and recurred in $80 \%$ afflicted patients [18-20]. The chief pathologic incidence in ACS is vaso-occlusion, the etiology of which is perhaps multifactorial. Abnormal adherence of sickle RBCs, WBCs and/or platelets to the vascular endothelium is one of the phenomenons causing vasoocclusion. The factors leading to cellular adhesion and vascular damage are not completely understood. Areas of ischemia/reperfusion build up during local vaso-occlusion. Oxidizing molecules for example $\mathrm{O}_{2}^{-}, \mathrm{H}_{2} \mathrm{O}_{2}, \cdot \mathrm{OH}$ radical and ONOO-are produced in large number during periods of reperfusion [21]. These compounds have ability to activate second messengers that causes up regulation of endothelial adhesion molecules. Molecules such as vascular cell adhesion molecule (VCAM)-1 and intercellular adhesion molecule (ICAM)-1, facilitate binding of sickle RBCs and WBCs to the vascular endothelium and thus may be responsible for vaso-occlusion [22-25]. Further, oxygenrelated species directly can damage endothelium by per-oxidation of the lipid membrane and/or DNA fragmentation, causing cellular

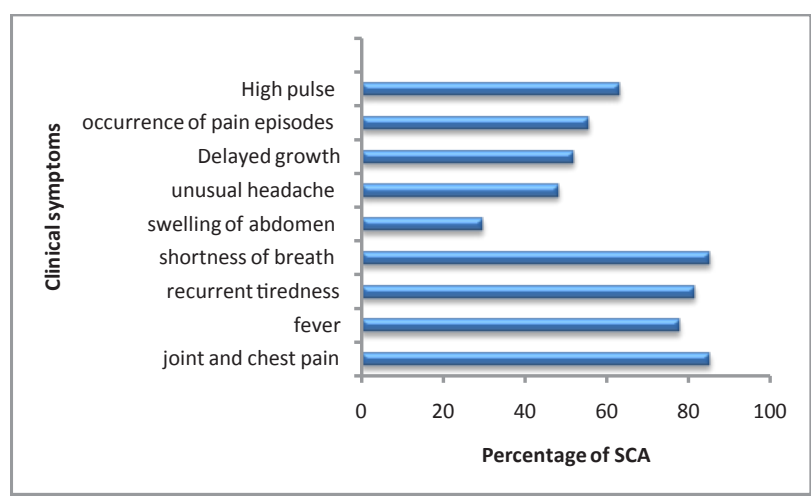

Figure 1: Some clinical complications presented by sickle cell anemic patients. apoptosis. SCD patients are subjected to great oxidative stress, mainly during vaso-occlusive crises (VOCs) and ACS [26]. It was stated that transgenic sickle cell mice had higher levels of oxidative stress markers, like ethane excretion and $\bullet \mathrm{OH}$ radical generation. During hypoxia, sickle cell mouse showed evidences of ischemia/reperfusion injury. This is represented by increased levels of oxygen radical and leukocyte adherence and emigration $[23,26]$. Within the renal tubular epithelium ONOO- are formed with associated cellular apoptosis [27]. Risk of stroke to sickle cell anemic child is 221 -fold higher than a healthy child [28]. Abnormal imaging is observed in sickle cell anemic patients. $46 \%$ sickle cell patients suffered from brain injury visible by MRI [29]. Niebanck et al. [30] reported cases of headache in sickle cell anemic patients. Many factors may involve in the symptoms of headache in sickle cell anemia and linked to migraine, VOE, bone marrow hyperplasia, OSA, or cerebral vessel stenosis [30].

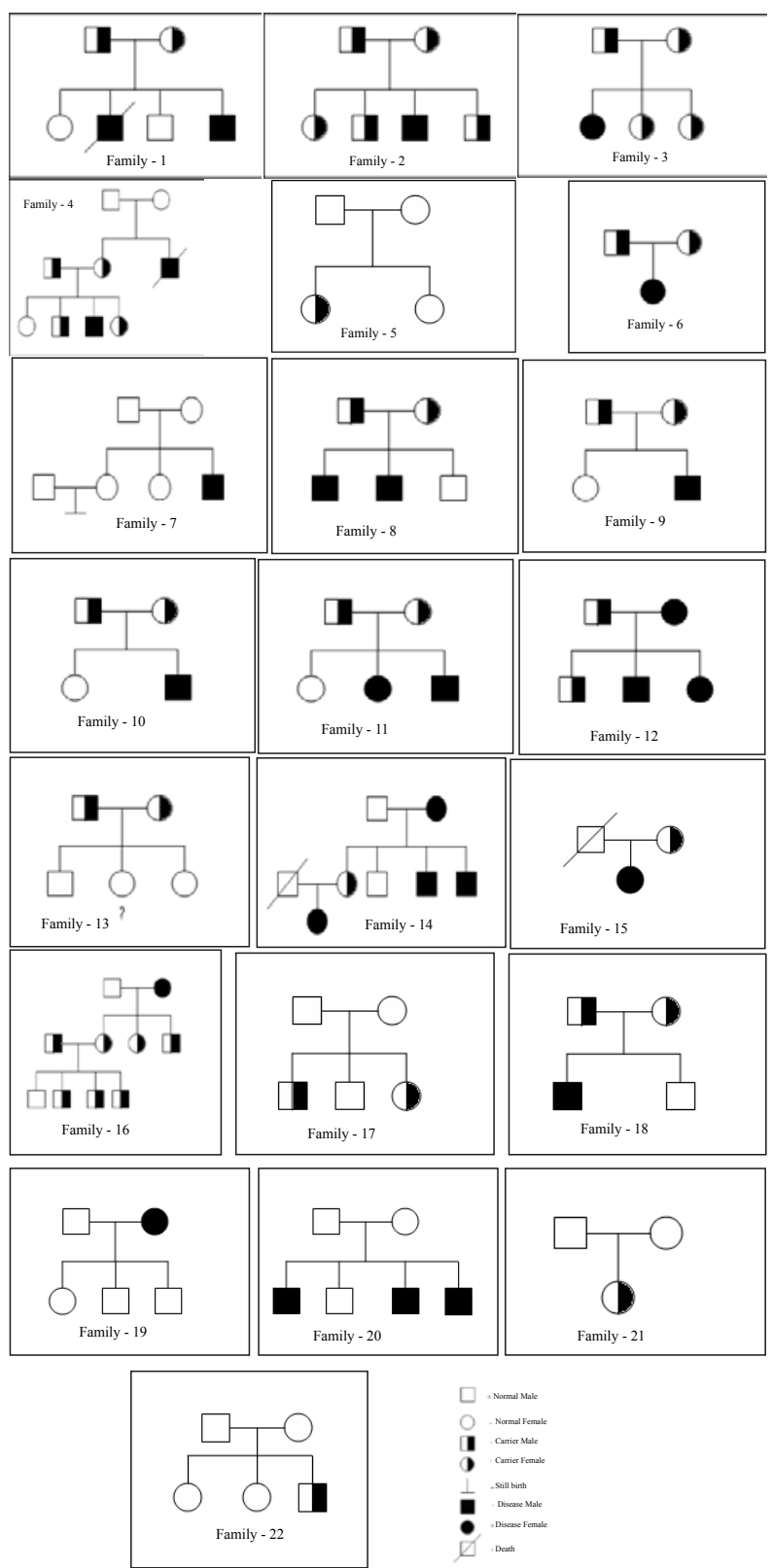

Figure 2: Pedigree analysis of sickle cell anemia in district Amravati, India. 
Citation: Wankhade V, Andhale RB, Lodha S (2013) Diverse Clinical manifestations in Sickle Cell Anemia: study in District Amravati, MS India. J Blood Disorders Transf 4:136. doi:10.4172/2155-9864.1000136

Page 3 of 3

In sickle cell anemia, tissue ischemia resulting in acute and multiorgan dysfunction is caused by intermittent episodes of vascular occlusion [31] which is characterized by chronic inflammation and ischemia-reperfusion injury [23,26,32]. Neutrophils have significant function in tissue damage [33]. Adhesion of lymphocytes and monocytes to the endothelium sickled induced by red blood cells may add to the pathogenesis of vascular occlusion [34]. The observations in the present study are in support of above mentioned studies.

\section{Pedigree analysis of sickle cell anemia in district Amravati}

It was found that in 12 families both the parents were carrier of the sickle cell gene. In 2 families death occurred due to sickle cell disorder. In 9 families sickle cell was absent in parents but appear in children due to mutation. In some families sickle cell anemia exist from many generations. In some families death of the family members had occure due to unknown diseases. In most of the families both the parents are carrier of sickle cell anemia. This may be due to marraiges in close relatives. Pedigree of some sickle cell anemic patients are expressed in the figure 2 .

\section{Conclusion and Recommendations}

Thus it could be concluded that the sickle cell anemic patients of district Amravati are under the great stress of the disease and should be treated and educated to manage the disease. Thus it is proposed to provide proper and immediate facilities to sickle cell patients to manage the complications.

Counseling and support can act as a potential factor to spread awareness in affected population. Health care workers who provide counseling should be properly educated to increase awareness about the disorders and, hopefully, help reduce the stigma attached to the disorders. There is a need to carry out more meticulous and larger-scale study regarding all aspects of sickle cell anemia.

\section{Acknowledgement}

The authors are grateful to Board of College and University Development, University of Pune for financial support. First author is thankful to Centre for advanced studies and DST-PURSE for partial financial support. We are thankful to Thalassemia Center, Jankalyan Blood Bank, Nashik and Mr.Narendra Manwar, Department of Zoology, University of Pune for their co-operation throughout the research work.

\section{References}

1. Ohene-Frempong K, Steinberg MH (2001) Clinical Aspects of Sickle Cell Anemia in Adults and Children. In: Steinberg MH, Forget BG, Higgs DR, Nage RL (Eds.). Disorders of Hemoglobin: Genetics, Pathophysiology and Clinical Management. Cambridge University Press, New York, USA, pp: 611-670.

2. Steinberg $\mathrm{MH}$ (2005) Predicting clinical severity in sickle cell anaemia. $\mathrm{Br} \mathrm{J}$ Haematol 129: 465-481.

3. PAULING L, ITANO HA, et al. (1949) Sickle cell anemia a molecular disease. Science 110: 543-548.

4. Eboh W, Van den Akker OA (1994) Antenatal care of women with sickle cell disease. Br J Midwifery 2: 6-11.

5. Serjeant GR (1997) Sickle-cell disease. Lancet 350: 725-730.

6. Lawrenz DR (1999) Sickle cell disease: a review and update of current therapy J Oral Maxillofac Surg 57: 171-178.

7. Platt OS, Brambilla DJ, Rosse WF, Milner PF, Castro O, et al. (1994) Mortality in sickle cell disease. Life expectancy and risk factors for early death. $\mathrm{N}$ Engl J Med 330: 1639-1644.

8. Frewin R, Henson A, Provan D (1997) ABC of clinical haematology Haematological emergencies. BMJ 314: 1333-1336.

9. Rahimy MC, Gangbo A, Ahouignan G, Alihonou E (2009) Newborn screening for sickle cell disease in the Republic of Benin. J Clin Pathol 62: 46-48.
10. Goddard JG, Sweeney GD (1983) Ferric nitrilotriacetate: a potent stimulant of in vivo lipid peroxidation in mice. Biochem Pharmacol 32: 3879-3882.

11. Hershko C, Link G, Konijn AM, Cabantchik ZI (2005) Objectives and mechanism of iron chelation therapy. Ann N Y Acad Sci 1054: 124-135.

12. Lester LA, Sodt PC, Hutcheon N, Arcilla RA (1990) Cardiac abnormalities in children with sickle cell anemia. Chest 98: 1169-1174.

13. Covarrubias EA, Sheikh MU, Solanki DL, Morjaria M, Fox LM (1980) Left ventricular function in sickle cell anemia: a noninvasive evaluation. South Med J 73: $342-344$

14. Gerry JL, Baird MG, Fortuin NJ (1976) Evaluation of left ventricular function in patients with sickle cell anemia. Am J Med 60: 968-972.

15. Reiter CD, Wang X, Tanus-Santos JE, Hogg N, Cannon RO 3rd, et al. (2002) Cell-free hemoglobin limits nitric oxide bioavailability in sickle-cell disease. Nat Med 8: 1383-1389.

16. De Caterina R, Libby P, Peng HB, Thannickal VJ, Rajavashisth TB, et al (1995) Nitric oxide decreases cytokine-induced endothelial activation. Nitric oxide selectively reduces endothelial expression of adhesion molecules and proinflammatory cytokines. J Clin Invest 96: 60-68.

17. Setty BN, Chen D, Stuart MJ (1996) Sickle red blood cells stimulate endothelia cell production of eicosanoids and diacylglycerol. J Lab Clin Med 128: 313-321.

18. Poncz M, Greenberg J, Gill FM, Cohen A (1985) Hematologic changes during acute chest syndrome in sickle cell disease. Am J Pediatr Hematol Oncol 7 : 96-99.

19. Johnson CS, Verdigem TD (1988) Pulmonary complications of sickle cell disease. Semin Respir Med 9: 287-296.

20. Vichinsky EP, Neumayr LD, Earles AN, Williams R, Lennette ET, et al. (2000) Causes and outcomes of the acute chest syndrome in sickle cell disease. National Acute Chest Syndrome Study Group. N Engl J Med 342: 1855-1865.

21. Dhalla NS, Elmoselhi AB, Hata T, Makino N (2000) Status of myocardial antioxidants in ischemia-reperfusion injury. Cardiovasc Res 47: 446-456.

22. Gee BE, Platt OS (1995) Sickle reticulocytes adhere to VCAM-1. Blood 85: 268-274.

23. Kaul DK, Hebbel RP (2000) Hypoxia/reoxygenation causes inflammatory response in transgenic sickle mice but not in normal mice. J Clin Invest 106 411-420.

24. Sultana C, Shen Y, Rattan V, Johnson C, Kalra VK (1998) Interaction of sickle erythrocytes with endothelial cells in the presence of endothelial cell conditioned medium induces oxidant stress leading to transendothelial migration of monocytes. Blood 92: 3924-3935.

25. Marui N, Offermann MK, Swerlick R, Kunsch C, Rosen CA, et al. (1993 Vascular cell adhesion molecule-1 (VCAM-1) gene transcription and expression are regulated through an antioxidant-sensitive mechanism in human vascular endothelial cells. J Clin Invest 92: 1866-1874.

26. Osarogiagbon UR, Choong S, Belcher JD, Vercellotti GM, Paller MS, et al. (2000) Reperfusion injury pathophysiology in sickle transgenic mice. Blood 96 : 314-320.

27. Bank N, Kiroycheva M, Ahmed F, Anthony GM, Fabry ME, et al. (1998) Peroxynitrite formation and apoptosis in transgenic sickle cell mouse kidneys. Kidney Int 54: 1520-1528.

28. Earley CJ, Kittner SJ, Feeser BR, Gardner J, Epstein A, et al. (1998) Stroke in children and sickle-cell disease: Baltimore-Washington Cooperative Young Stroke Study. Neurology 51: 169-176.

29. Steen RG, Xiong X, Langston JW, Helton KJ (2003) Brain injury in children with sickle cell disease: prevalence and etiology. Ann Neurol 54: 564-572.

30. Niebanck AE, Pollock AN, Smith-Whitley K, Raffini LJ, Zimmerman RA, et al (2007) Headache in children with sickle cell disease: prevalence and associated factors. J Pediatr 151: 67-72, 72.

31. Lane PA (1996) Sickle cell disease. Pediatr Clin North Am 43: 639-664.

32. Reiter CD, Gladwin MT (2003) An emerging role for nitric oxide in sickle cell disease vascular homeostasis and therapy. Curr Opin Hematol 10: 99-107.

33. Lard LR, Mul FP, de Haas M, Roos D, Duits AJ (1999) Neutrophil activation in sickle cell disease. J Leukoc Biol 66: 411-415.

34. Zennadi R, Chien A, Xu K, Batchvarova M, Telen MJ (2008) Sickle red cells induce adhesion of lymphocytes and monocytes to endothelium. Blood 112 3474-3483. 